\title{
Research Square \\ Isatin inhibits LSD1 regulated autophagy through SESN2-mTOR signaling pathway in neuroblastoma
}

\section{Xue Li}

Qingdao University Medical College

\section{Li Zhang}

Qingdao University Medical College

\section{Yiming Nai}

Qingdao University Medical College

\section{Fangling Wang}

Qingdao University Medical College

\section{Yanan Hua}

Qingdao University Medical College

Na Zhou

Qingdao University Medical College

Jun Wang

Qingdao University Medical College

Wenxiang Zheng

Qingdao University Medical College

Lin Hou ( $\nabla$ qingyi001@126.com )

Qingdao University Medical College https://orcid.org/0000-0002-9061-9792

\section{Research article}

Keywords: Isatin, Autophagy, Neuroblastoma, LSD1, SESN2

Posted Date: February 29th, 2020

DOI: https://doi.org/10.21203/rs.3.rs-15495/v1

License: (c) (1) This work is licensed under a Creative Commons Attribution 4.0 International License.

Read Full License 


\section{Isatin inhibits LSD1 regulated autophagy through SESN2-mTOR signaling pathway in neuroblastoma}

\section{Xue Li ${ }^{1}$, Li Zhang ${ }^{2}$,Yiming Nai ${ }^{1}$,Fangling Wang ${ }^{1}$,Yanan Hua ${ }^{1}, \mathrm{Na}$ Zhou ${ }^{1}$, Jun Wang ${ }^{1}$, Wenxiang Zheng ${ }^{1}$, Lin $\mathrm{Hou}^{3}$}

1Department of Biochemistry and Molecular Biology, School of Basic Medicine, Qingdao University, Qingdao, China. Shandong 266021, P.R. China. 2Experimental Center for Undergraduates of Pharmacy, School of Pharmacy; Qingdao University, Qingdao, Shandong 266021, P.R. China. 3 Department of Biochemistry and Molecular Biology, School of Basic Medicine, Qingdao University, Qingdao, China. Shandong 266021, P.R.

China.qingyi001@126.com, ORCID iD: 0000-0002-9061-9792.

\section{Abstract:}

Neuroblastoma (NB) is common in the pediatric tumors with low cure rate and high mortality, drug resistance makes chemotherapy more difficult, it threaten to children's health seriously. $1 \mathrm{H}$-indole-2, 3-dione (isatin) is a second-hand of derivative of anticarcinogen indirubin which had been shown to be a monoamine oxidase inhibitor and have antitumor activity, in this study, we explained that $\mathrm{SH}-\mathrm{SY} 5 \mathrm{Y}$ cells was add to isatin at a dose-dependent level ranging from 50 to $200 \mu \mathrm{mol} / \mathrm{L}$ were capable of inhibiting tumor cell growth, included triggering apoptosis and inhibiting proliferation, invasion and metastasis, and assessed the potential anticancer capability of isatin on the induction of autophagy. The experimental result showed that cell SH-SY5Y disposed with isatin could induce autophagy effectively, at the same time, it also help suppress the growth of tumor cells. Furthermore, the article indicated that the induction of autophagy of isatin-mediated occurred in inhibition-lysine-specific demethylase 1(LSD1) and sestrin2 (SESN2) - 
dependent manner. Furthermore, we identified that SH-SY5Y cells after treating with isatin induced SESN2 expression via a mTOR-dependent signal pathway, which mechanism is that isatin inhibit LSD1-enzyme activation and combine the promoter regions of SESN2, so that given rise to a significant transcriptional induction of SESN2. In addition, western blot analysis indicated that SH-SY5Y cells with isatin-exposed can regulated activity of LC-3, Beclin1 and p62 which are correlated with autophagy. Collectively, all the results from this study illistrated that adding to isatin could occur to induce autophagy and restrain NB cell SH-SY5Y growth through mTOR-dependent transcriptional induction of SESN2, this supplied a new mechanism for understanding the anti-tumor ability of isatin on NB. Taken together, this paper demonstrate that isatin is a promising candidate for treating NB.

Keywords: Isatin, Autophagy, Neuroblastoma, LSD1, SESN2

\section{Introduction:}

Neuroblastoma (NB) is an usual extracranial solid cancer in babyhood and childhood, the case fatality rate is high, approximately $15 \%$, the incidence of NB are from 5.9 among to 10.5 per million children which the age are under 15 years[1]. The adrenal gland is the most common site to have NB, but sometimes it can occur in the chest, abdomen, neck, and pelvic nerve tissue too[2]. According to report, NB is characterized by heterogeneity, it may recover spontaneously in the absence of treatment, or may hanppen 
deterioate and metastasize, and it appear to resistance to antitumor drug therapy[3]. At present, there have recurrence and poor prognosis after therapy in many high-risk NB[4]. Hence it is importance to investigate a new drug to therapy NB. With the application of natural antineoplastic drugs in clinical, the antitumor function of the indole compounds increasingly aroused people's concern. Indoline-2,3-dione or indole-1H-2,3-dione(isatin), is a wellknown natural product which found in plants of genus isatis and in couropita guianancis aubl[5]. The first extraction of isatin was as an oxidation product of indigo, and Kekule proposed its its structure, and it was isolated as a metabolic derivative of adrenaline in humans too[5, 6]. In recent years, isatin has received more and more attention from researchers. From previous research reports, isatin has the advantages of small molecular weight and low toxicity, as a derivative of the anticarcinogen indirubin, isatin has many beneficial biological activities, including antifungal, antibacterial anticancer capabilities[7, 8]. From what has been discussed above, isatin had its characteristics and advantage which can be potential to exploit as a natural small molecule compounds anti-tumor drug.

Previous studies have shown that isatin is an endogenous indole which can suppress monoamine oxidase $\mathrm{B}(\mathrm{MAOB})$ and can cause the death of $\mathrm{SH}$ SY5Y cell in a method of dose-dependent and time-dependent $[9,10]$. However, the mechanism involved anti-tumor activity of isatin is incompletely understood. 
The occurrence and development of NB is related with the expression of protein and regulation of signaling pathways. The report suggested that the monoamine oxidase (MAO) expression was likely to relate to the neoplasia, after depriving growth factor, in various neuronal cells there occur to apoptotic cell death atfter the activity of MAO[11, 12]. Up to date, some reports proved that the alterations of epigenetic was able to regulate autophagy, such as histone methylation and acetylation[13-15]. However, it had not explained the mechanisms that the cancer associated alterations of epigenetic could regulate autophagy. The lysine-specific demethylase1(LSD1), is an epigenetic enzyme, also as an amine oxidase which can promote lysine demethylation in a flavin adenine dinucleotide dependent oxidative reaction and removes mono- and dimethyl groups from lysine K4, and in specific circumstances, $\mathrm{K} 9$ on histone $\mathrm{H} 3[16-18]$. Lately, there has been reported that the neuron specific isoform LSD1 has a new substrate specificity, targeting histone H4 Lys 20[19]. Moreover, there are some non-histone proteins are targeted by LSD1, like E2F1, DNMT and p53[20-22]. LSD1 has been proved to have important roles in many aspects of cell biology, like cell differentiation, cell proliferation and mobility[23-25].In addition, LSD1 gene is highly expressed in many types tumors, the overexpression of LSD1 is often associated with malignancy and poor prognosis. According to report, LSD1 has some effect on keeping the malignant phenotype and undifferentiated of NB cells[26]. It has reportly involved in the progression of malignant in various 
tumors, including ER-negative breast cancer and primary NB[26, 27], and poorly differentiated NB [28]. LSD1 as a kind of MAO, it was be bound up with apoptosis, metastasis and invasion of neoplasm. As a kind of epigenetic marker, the overexpression of LSD1 is one of the marker of tumor progression [29, 30]. A lot of evidence indicated that in the incidence and development of tumors LSD1 had an critical role and can be a new target gene for tumor treatment. According to the above, as a member of MAO inhibitor, isatin might had an effect on LSD1 directly, therefore, LSD1 is likely to be a potential target of isatin for tumor inhibition.

Sestrin2 (SESN2), a protein which has characteristic with highly evolutionarily conserved, participated in many physiological functions of cells, including regulating autophagy with downregulating the protein kinase in signaling pathway of mammalian target of rapamycin (mTOR) [31]. According to literature reports, LSD1 can combine Sesn2 promoter regions so as to regulate SESN2 expression, thereby inhibiting the activation of mTOR, finally, by regulating the activity of autophagy - related proteins to play a role in cancer inhibition[32]. In summary, SESN2 is also an novel target of curing the cancer by regulating the autophagy mTOR signaling pathway. Previous reports have suggested that from the microarray data, $\mathrm{SH}-\mathrm{SY} 5 \mathrm{Y}$ cells were treatment with isatin and untreatment controls were closely related to the mTOR signaling pathway, and connected with the genes of mTOR downstream which taken part in autophagy[33]. Form the results of this article, 
it offered an new mechanism to understand the inhibitory effect of isatin on NB.

All these evidences support the potential antitumor function of the new drug named isatin on NB cells, and the mechanism was likely to be inhibited LSD1 regulated autophagy through SESN2-mTOR signaling pathway. Taken together, isatin has the potential to be developed as an anticancer drug to inhibit neuroblastoma.

\section{MATERIALS AND METHODS}

\subsection{Cell culture and treatments}

Human neuroblastoma (SH-SY5Y)cells which were buy from Peking Union Medical College. DMEM (HyClone; GE Healthcare Life Sciences) were used to culture cells with $10 \%$ fetal bovine serum (BI; California, USA) supplemented at $37^{\circ} \mathrm{C}$ in a humidified atmosphere with $5 \% \mathrm{CO}_{2}$. The drug (Isatin) was dissolved in $0.1 \%$ dimethyl sulfoxide, than put it to culture dish at concentrations of $0,50,100,200 \mu \mathrm{mol} / \mathrm{L}$, after the cells had grow to about $\sim 70 \%$ proportion. The cells were harvested after treatment with isatin at $37^{\circ} \mathrm{C}$ for $48 \mathrm{~h}$ for further application and analysis.

\subsection{CCK-8 assay}

It used CCK-8 assay to detect the inhibition rate and toxicity of isatin on $\mathrm{SH}$ SY5Y cells. A 96-well plate was used to culture the SH-SY5Y cells steady with a final volume of $100 \mu \mathrm{l}$ of complete culture medium, the different concentrations $(0,25,50,100,200,400,800 \mu \mathrm{mol} / \mathrm{L})$ of isatin(five wells for 
each concentration) were treated with SH-SY5Ycells when the it grow to about $60 \%$ and incubated for $24 \mathrm{~h} / 48 \mathrm{~h} / 72 \mathrm{~h}$ at $37^{\circ} \mathrm{C}$ in a humidified atmosphere with $5 \% \mathrm{CO}_{2}$. Aftertreatment, $10 \mu \mathrm{l} \mathrm{CCK-8} \mathrm{solution} \mathrm{was} \mathrm{added} \mathrm{to}$ each well and incubated at $37^{\circ} \mathrm{C}$ for $2 \mathrm{~h}$. Then the absorbance of the samples was measured at $450 \mathrm{~nm}$ with a Microplate Reader (SynergyH1; Bio Tek, Vermont, USA). Each independent experiment was run for three times. According to the formula to calculate isatin inhibition rate of SH-SY5Y cells and IC50(used SPSS Statistics).

\subsection{Cell morphological changes of the experiment}

The 6-well plate were used to culture SH-SY5Y cells, when it spread to $60 \%$ in the total volume of $2 \mathrm{ml}$ complete medium, exposed with isatin in different concentrations $(0,50,100,200 \mu \mathrm{mol} / \mathrm{L})$ for $48 \mathrm{~h}$, the cells morphology changes was observed by electron microscope, the pictures were taken by microscope.

\subsection{Cell invasion and migration assay.}

SH-SY5Y Cells $\left(\approx 1 \times 10^{6}\right)$ were cultured in a 6 -well plates and added to isatin with different concentrations $(0,50,100,200 \mu \mathrm{mol} / \mathrm{L})$ at $37^{\circ} \mathrm{C}$ for $48 \mathrm{~h}$. The cell invasion was used by a wound healing assay to monitor. Used A micropipette tip to scratch and create a wound in each well (horizontal and vertical scratch three lines each well). Often observe the cells growth state, and taken pictures at different time $(0,24,36,48 \mathrm{~h})$ by electron microscope. The transwell invasion assay was performed in Boyden chambers (Millipore, 
California, USA). About $2 \times 10^{5}$ cells per well seeded in $200 \mu \mathrm{l}$ of serum-free medium and pre-added to isatin for $48 \mathrm{~h}$ were put in the upper chamber with Matrigel, and the DMEM supplemented with $10 \%$ FBS was put in the lower chamber. After the incubation, removed the SH-SY5Y cells from the upper surface completely, and the filter was fixed in methanol and used crystal violet to stain. Cells invading the Matrigel were counted under an inverted microscope. Data were expressed as the average cell number in five fields and the experiment was repeated thrice in the same conditions.

\subsection{Flow cytometry to detect cell apoptosis}

Flow cytometry (Annexin V APC Apoptosis Detection kit) was used to determine cells apoptosis. $100 \mu \mathrm{l} 1 \times$ Binding Buffer used to suspend with approximately $2 \times 10^{6}$ cells, and disposed of $5 \mu$ Annexin V APC. Then, added $300 \mu \mathrm{l} 1 \times$ Binding Buffer to centrifuge for $5 \mathrm{~min}$ at 1000rpm and threw away the supernatant, the addition of $10 \mathrm{~mL} \mathrm{PI}$ dye were put to inincubate for another 5 min. The BD Accuri C6 Software was used to analysis the results.

\subsection{Flow cytometry to detect cell cycle}

Flow cytometry was used to determine cell cycle. SH-SY5Y cells $\left(3 \times 10^{6} / \mathrm{mL}\right)$ were starved for $48 \mathrm{~h}$ treatment with isatin, then fixed with $70 \%$ ethanol overnight. Next, mixed $200 \mathrm{ul} 1 \times$ PBS with $2 \mu \mathrm{l}$ RNAase $(0.25 \mathrm{mg} / \mathrm{ml})$, then hatched at $37^{\circ} \mathrm{C}$ and stained cells with $500 \mathrm{~mL}$ propidium iodide (PI; Roche, Switzerland) in a dark environment. Detected on machine (BD Accuri C6 Software) and analyzed the results with Flowjo software. 


\subsection{Tablet cloning}

SH-SY5Y cells $\left(\approx 1 \times 10^{6}\right)$ were used of trypsin digestion and inoculated in 6well plates with proper density (500 cells per / hole), cultured at $37^{\circ} \mathrm{C}$ and added to isatin with different concentration $(0,50,100,200 \mu \mathrm{mol} / \mathrm{L})$ when the cells appear to stick wall, keep on culturing cells when cloning appear visible to the naked eye; methanol fix for $10 \mathrm{~min}$; Crystal violet staining for $10 \mathrm{~min}$.

\subsection{DAPI staining to detect apoptosis}

SY5Y cells were cultured in the 24-well plate treatment like previous for $48 \mathrm{~h}$. Remove the medium washed with $1 \times$ PBS;add $100 \mu$ methyl alcohol to fixate cells for $5 \mathrm{~min}$; depleting methyl alcohol and washed with $1 \times$ PBS, add in 500 $\mu$ I DAPI staining fluid for $5 \mathrm{~min}$ at room temperature; Discarding the dyeing liquid and washed with $1 \times$ PBS for 3 min for 3 times; Each group were taken using fluorescence microscope at $\times 200$ for three times.

\subsection{Quantitative RT-PCR assay.}

The extraction of total RNA of SH-SY5Y cells were used with trizol reagent (Solarbio, Beijing, China). The template cDNA was used a reverse transcription kit (Transgene, Beijing, China) to construct, and qPCR with Trans Start Probe RT-PCR Super Mix (Transgene, Beijing, China). The data were obtained on Bio-Rad (California, USA) One-Step Plus system. The primer sequences used are shown in Table 1.

Table 1. The primer sequences used in q-PCR

Gene Forward Reverse


GAPDH 5'-CGTGGAAGGACTCATGACCA-3'

5'-TCCAGGGGTCTTACTCCTTG-3'

\begin{tabular}{lcc}
\hline LSD1 & 5'-GGCAGCAGCTCGACAGTTACAA-3' & 5'-TACCACCATGGCTCCAAGATCA-3' \\
\hline SESN2 & 5'-ATACCATCGCCATGCACAGT-3' & 5'-GTGGACCTTCTCTGAGTGGC-3' \\
\hline Beclin1 & 5'-CCATGCAGGTGAGCTTCGT-3' & 5'-GAATCTGCGAGAGACACCATC-3' \\
\hline P62 & 5'-GCACCCCAATGTGATCTGC-3 & 5'-CGCTACACAAGTCGTAGTCTGG-3' \\
\hline LC3 & 5'-AAGGCGCTTACAGCTCAATG-3' & 5'-CTGGGAGGCATAGACCATGT-3' \\
\hline
\end{tabular}

\subsection{Protein extraction and western blot analysis}

$\mathrm{SH}-\mathrm{SY} 5 \mathrm{Y}$ cells were cultured at $37^{\circ} \mathrm{C}$ when is attained to $60 \%$ were supplemented with Isatin for 48h, then RIPA lysis buffer used to dissolved cells (Beyotime Institute of Biotechnology). Extracted the total protein from lysis liquid, the concentration of protein was detected with bicinchoninic acid protein assay. SDS-polyacrylamide gels (8-12\%) used to separate Total protein (Concentration will be dispatched to $4 \mu \mathrm{g} / \mu \mathrm{l}$ using RIPA) and perform the membrane operation in PVDF. Then close it at room temperature for $2 \mathrm{~h}$, and the primary antibody was incubated with 5\% BSA diluent: p-mTOR (1:5,000; cat. no. ab109268; $\beta$-actin (1:3,000; cat. no. ab8227; Abcam), Abcam), LC3 (1:1,000; cat. no. 3868; CST), P62 (1:1,000; cat. no. 5114; CST), Beclin-1 (1:1,000; cat. no. 3738; CST) at $4^{\circ} \mathrm{C}$ overnight, $1 \times$ TBST to wash for three times 5 min for each. Second antibodies were incubated for $1 \mathrm{~h}$ at the normal temperature. Wash the film three times. Using the machine to detect the expression of protein (Enhanced Chemiluminescence Plus kit ;Wuhan Boster Biological Technology, Ltd.) and Quantitative analysis using software (version 4.52; Bio-Rad Laboratories, Inc.). 


\subsection{Statistical analysis}

All experimental data were performed three times and used the mean \pm standard deviation (SD) to calculate. The data were statistically analyzed by one-way variance (ANOVA) and pairwise comparison by using statistical software (GraphPad Prism 6), P $<0.05$ was considered statistically significant.

\section{Results:}

\subsection{Isatin inhibited the proliferation of SH-SY5Y cells}

The results of CCK-8 assay showed that isatin could suppress the proliferation of $\mathrm{SH}-\mathrm{SY} 5 \mathrm{Y}$ cells, and the inhibition rate is increasingly dosedependent of isatin. After the test we found that the most obvious inhibition effect of SH-SY5Y was treatment with isatin for $48 \mathrm{~h}$ (Fig.1a). The IC50 of isatin is $271.31 \mu \mathrm{mol} / \mathrm{L}$ calculated by software (SPSS Statistics 7). According to the results we selected $0,50,100$ and $200 \mu \mathrm{mol} / \mathrm{L}$ concentrations for experimental study. Tablet cloning found that after adding to isatin the formation of the colony number of SH-SY5Y cells on 6-well plate less and less compared with the control group, it suggested that isatin could control the proliferation of $\mathrm{SH}$ SY5Y cells (Fig.1b).
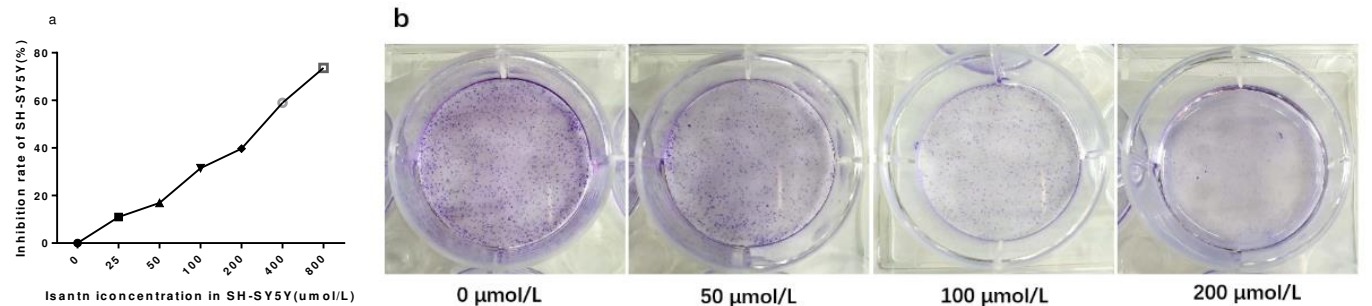

Fig. 1 Isatin inhibited SH-SY5Y cells proliferation. a CCK-8 assay showed that isatin inhibited the proliferation of SH-SY5Y cells. b Tablet cloning showed SH-SY5Y cells were treatment with $0 \mu \mathrm{mol} / \mathrm{L}, 50 \mu \mathrm{mol} / \mathrm{L}, 100 \mu \mathrm{mol} / \mathrm{L}, 200 \mu \mathrm{mol} / \mathrm{L}$ isatin for $48 \mathrm{~h}$, cell cloning was significantly inhibited.

\subsection{Cell morphological changed of the experiment}


After treating with isatin for $48 \mathrm{~h}$, the SH-SY5Y cells morphology changed that the nucleus appeared pyknosis and cells fragment became increased, the number of living cells decreased significantly with more doses of isatin (Fig.2). Therefore we think that isatin can obviously inhibit growth of SH-SY5Y cells.

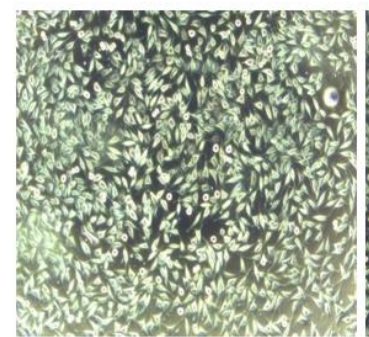

$0 \mu \mathrm{mol} / \mathrm{L}$

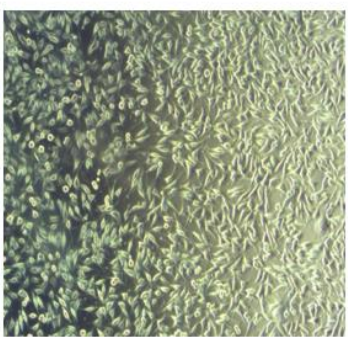

$50 \mu \mathrm{mol} / \mathrm{L}$

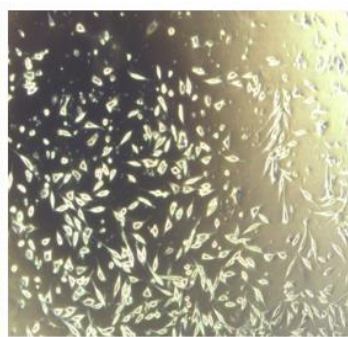

$100 \mu \mathrm{mol} / \mathrm{L}$

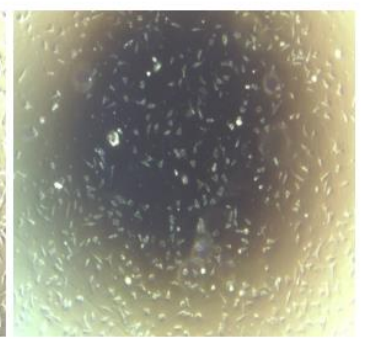

$200 \mu \mathrm{mol} / \mathrm{L}$

Fig. $2 \mathrm{SH}-\mathrm{SY} 5 \mathrm{Y}$ cells were treatment with isatin for $48 \mathrm{~h}$, Cell morphology changed.

\subsection{Flow cytometry to detect cell cycle and apoptosis}

After treating with isatin for $48 \mathrm{~h}$. It's found that cell cycle of SH-SY5Y cells were changed by using flow cytometry to detect. The proportion of $S$ phase decreased significantly, cells obviously were block in phase G1(Fig.3a c). Flow cytometry to detect cell cycle apoptosis, the number of living cells decreased obviously with more doses of isatin (Fig. 3b d). The proportion of the early apoptotic cells and the late apoptosis cells were more and more with isatin increased. From the results, we speculate that isatin can obviously increase the SH-SY5Y cell apoptosis rate.

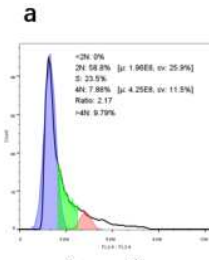

$0 \mu \mathrm{mol} / \mathrm{L}$

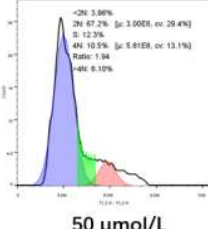

$50 \mu \mathrm{mol} / \mathrm{L}$

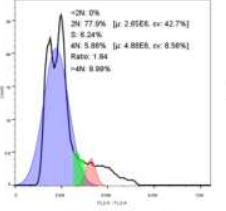

$100 \mu \mathrm{mol} / \mathrm{L}$

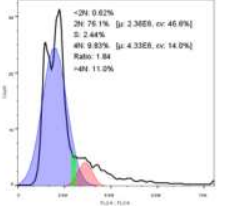

$200 \mu \mathrm{mol} / \mathrm{L}$

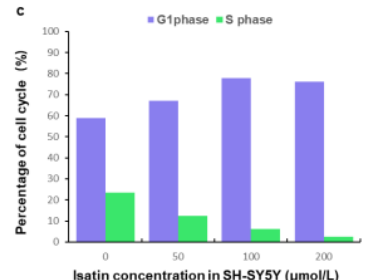




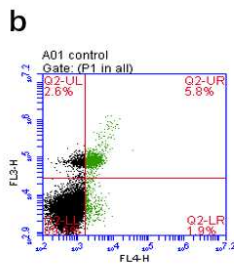

$0 \mu \mathrm{mol} / \mathrm{L}$

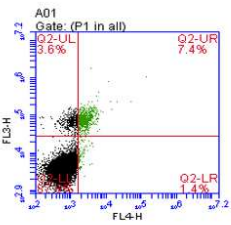

$50 \mu \mathrm{mol} / \mathrm{L}$

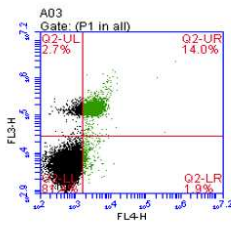

$100 \mu \mathrm{mol} / \mathrm{L}$

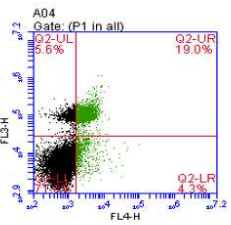

$200 \mu \mathrm{mol} / \mathrm{L}$

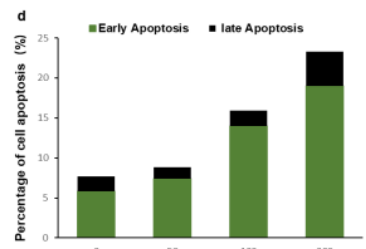

Isatin concentration in SH-SYSY (MmollL)

Fig. 3 Flow cytometry to detect cell cycle and apoptosis. A SH-SY5Y cells were treatment with different isatin, flow cytometry to detect the change of cell cycle. B SHSY5Y cells were treatment with different concentrations isatin, flow cytometry to detect the change of cell apoptosis. $\mathbf{c}$ was percentage of cell cycle after adding to different concentrations isatin in SH-SY5Y cells from a. $\mathbf{d}$ was percentage of cell apoptosis after adding to different concentrations isatin in SH-SY5Y cells from $\mathbf{b}$.

\subsection{DAPI staining to detect apoptosis}

After SH-SY5Y cells were treatment with isatin for 48h, DAPI staining to detect cell apoptosis. Compared with the blank control group, cell morphology changed after join isatin (Fig. 4), the morphology changed more obvious with the increase of concentration, we can see cytoplasmic concentrated from the picture, and the nucleus had become more shrunk, shiny and turn round, these suggested that the apoptosis of SH-SY5Y cells were increased, The results showed that isatin can promote apoptosis, which is more obvious with the increase of drug concentration.

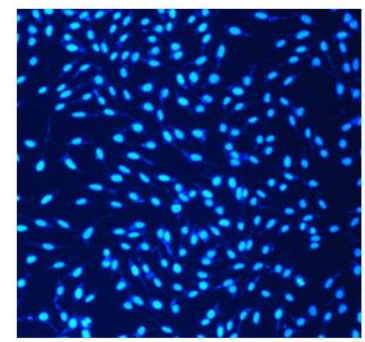

$0 \mu \mathrm{mol} / \mathrm{L}$

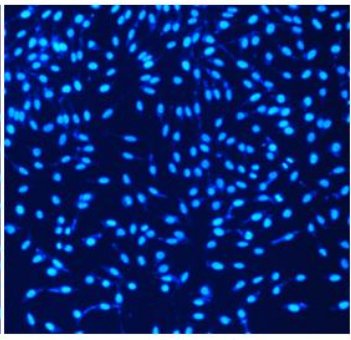

$50 \mu \mathrm{mol} / \mathrm{L}$

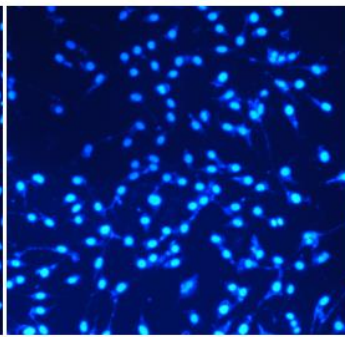

$100 \mu \mathrm{mol} / \mathrm{L}$

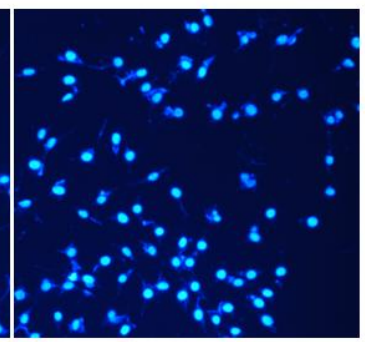

$200 \mu \mathrm{mol} / \mathrm{L}$

Fig.4 DAPI staining to detect apoptosis. SH-SY5Y cells were treatment with $0 \mu \mathrm{mol} / \mathrm{L}, 50$ $\mu \mathrm{mol} / \mathrm{L}, 100 \mu \mathrm{mol} / \mathrm{L}, 200 \mu \mathrm{mol} / \mathrm{L}$ isatin, the morphology of the nucleus changed.

\subsection{Isatin suppressed invasion and migration of $\mathrm{SH}-\mathrm{SY} 5 \mathrm{Y}$ cells}

After cells were treatment with isatin for $48 \mathrm{~h}$, the scratch test of $\mathrm{SH}-\mathrm{SY} 5 \mathrm{Y}$ cell 
was taken to detect migration ability. The results showed that the scratches healed more slowly in the treatment group than in the control group (Fig. 5b). Using transwell detected the ability of cell invasion. The results showed that with the concentration of the drug was higher, the ability of cells through the small room is more and more low compared with controls. All the above experimental results showed that isatin had a significant inhibitory effect on the invasion and migration of neuroblastoma cells (Fig. 5a).

\section{a}

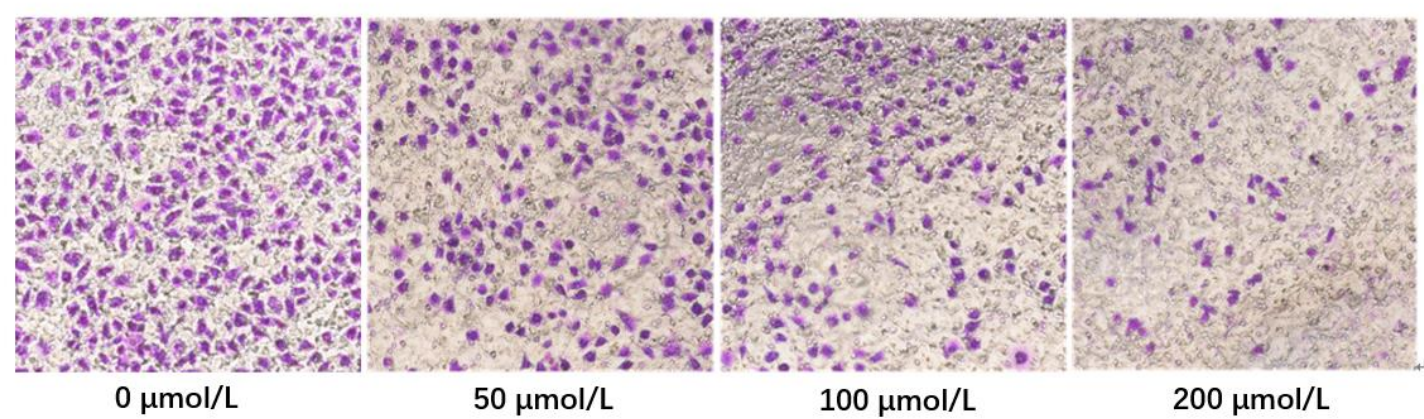

b
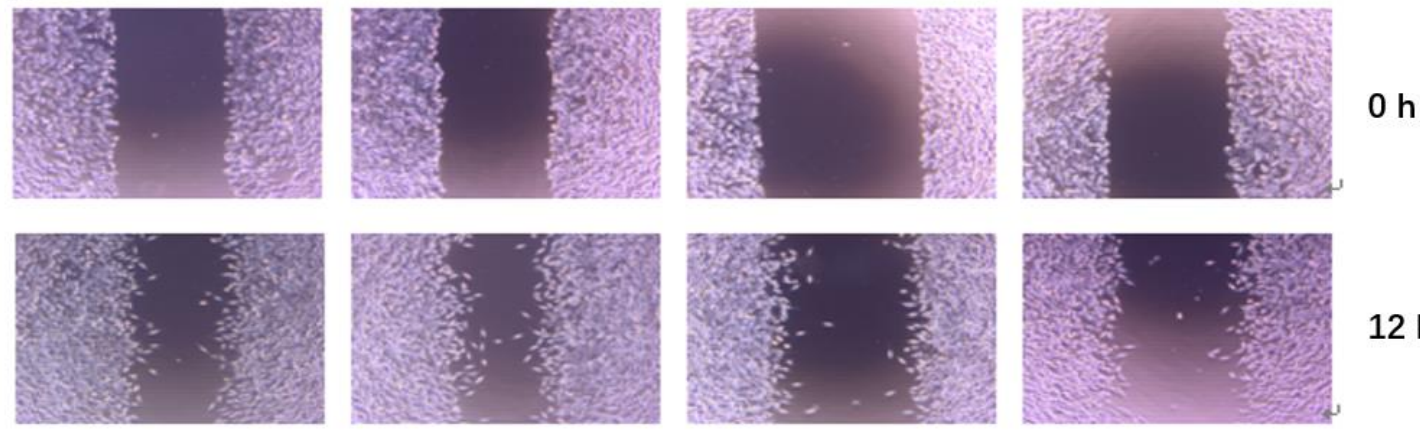

$12 \mathrm{~h}$
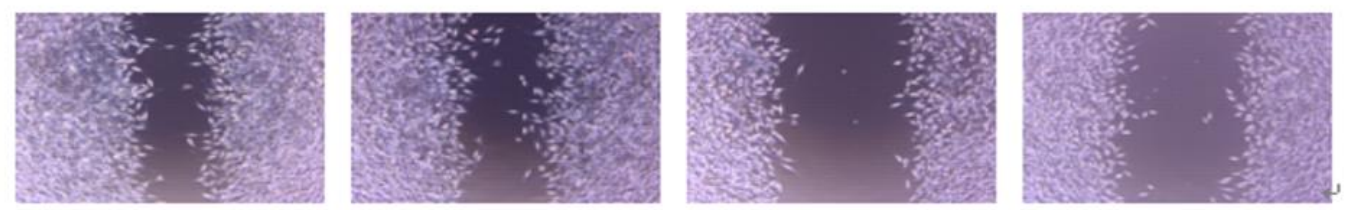

$24 \mathrm{~h}$

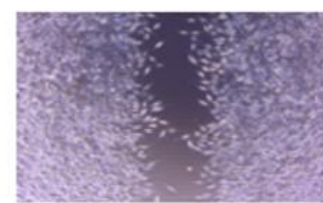

$0 \mu \mathrm{mol} / \mathrm{L}$

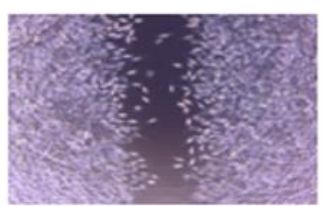

$50 \mu \mathrm{mol} / \mathrm{L}$

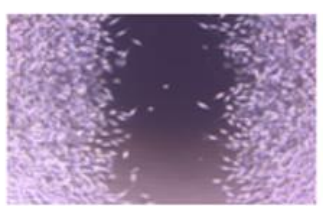

$100 \mu \mathrm{mol} / \mathrm{L}$

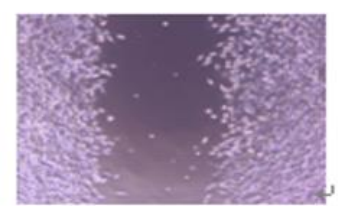

$200 \mu \mathrm{mol} / \mathrm{L}$

Fig. 5 Isatin suppressed SH-SY5Y cells invasion and migration. a SH-SY5Y cells were 
treatment with $0 \mu \mathrm{mol} / \mathrm{L}, 50 \mu \mathrm{mol} / \mathrm{L}, 100 \mu \mathrm{mol} / \mathrm{L}, 200 \mu \mathrm{mol} / \mathrm{L}$ isatin, the invasion of cells were obviously inhibited. $\mathbf{b}$ SH-SY5Y cells were treatment with $0 \mu \mathrm{mol} / \mathrm{L}, 50 \mu \mathrm{mol} / \mathrm{L}, 100$ $\mu \mathrm{mol} / \mathrm{L}, 200 \mu \mathrm{mol} / \mathrm{L}$ isatin, the migration of cells was obviously inhibited.

\subsection{Quantitative RT-PCR assay.}

After SH-SY5Y cells treated as before, we detected the mRNA relative expression of LSD1, SESN2, p53, Beclin1, P62 and LC3, from the results (Fig. 6), we found that LSD1, P62 mRNA relative expression appear trend of less compared to the control group $(P<0.01)$, meanwhile SESN2, p53, Beclin1, LC3 mRNA expression increased compared with the control variable $(\mathrm{P}<0.01)$. It illustrated that isatin could induce related genes expression, thus control the physiological and biochemical changes of SH-SY5Y cells. It also suggested that after joining isatin, the expression of related gene changed which affected SH-SY5Y cells proliferation, apoptosis, autophagy, so as to inhibit tumor cell growth and metastasis.
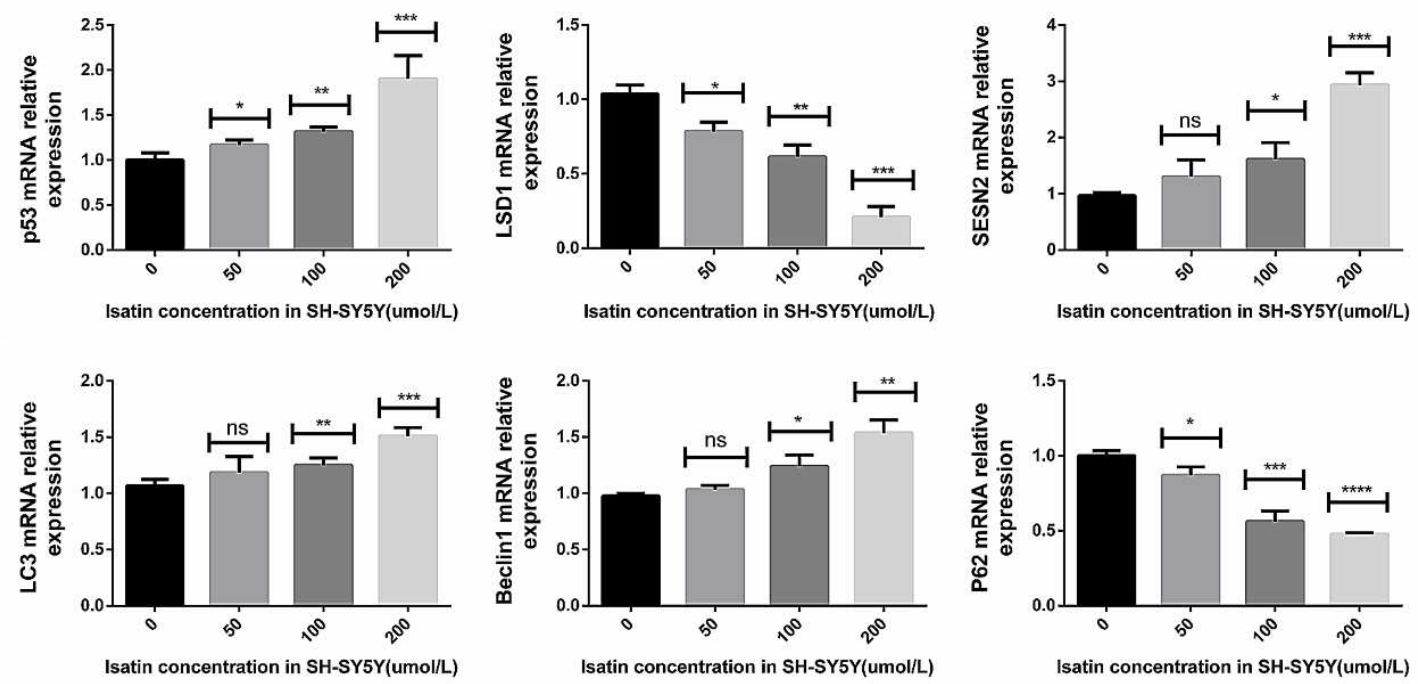

Fig. 6 q-PCR assay detect mRNA relative expression. In SH-SY5Y cells p53, LSD1, SESN2, Beclin1, P62 and LC3 changed $(P<0.01)$ after adding to different concentrations 
isatin for $48 \mathrm{~h}$.

\subsection{Western Blot and Sample Western analysis}

\subsubsection{Isatin can inhibit the enzyme activity of LSD1}

It is reported that isatin can restrain activity of MAO. Because of LSD1 is one of MAO so we guess if isatin as one of MAO inhibitor can work on LSD1 directly. The results from qPCR and the western blot were found that the mRNA relative expression level of LSD1 occurred to decline after treatment with isatin, similarly, the relative expression level of the protein decreased (Fig. 7a). These results showed that isatin as MAOI can directly inhibit the expression of LSD1 enzyme acted like as an inhibitor.

\subsubsection{LSD1-depentent epigenetic induced SESN2 expression represses the mTOR pathway}

The results of Western Blot showed that SH-SY5Y cells after adding to isatin $48 \mathrm{~h}$, SESN2 relative protein expression was increased (Fig. 7a), and mTOR relative protein expression reduced (Fig. 7b), the result explained that the mechanism of isatin inhibiting SH-SY5Y cells must be relevant to SESN2 and mTOR. Here, it identified that as an LSD1-repressed gene SESN2 participated in mTORC1 signal routing from KEGG. From the report SESN2 promoter was directly bound and repressed by LSD1. Pharmacological inhibition of LSD1 triggers a structural modeling in the chromatin surrounding the TSS of the SESN2 gene, leading to transcriptional activation of SESN2 expression. Previous studies (the microarray data) shown that isatin-treated cells and untreated controls were associated with the mTOR signaling 
pathway[34]. These results suggested that isatin had a significant inhibitory effect on NB cells, and the mechanism was likely to involve SESN2.

\subsubsection{Autophagy related protein expression changed after treating with} isatin

The results of Western Blot showed that SH-SY5Y cells after adding to isatin for $48 \mathrm{~h}$, the protein levels of LC3, Beclin1and P62 had changed (Fig. 7b). The mTOR pathway play an important role in the occurrence of autophagy. Including LC3 is also a marker associated with autophagy. It is reported that LC3-II gene expression in the membrane of autophagosomes reflected the level of autophagy [35, 36]. The experimental results showed that LC3 protein expression level increased, which mean the level of autophagy increased. P62 expression is also an important marker to reflect autophagy. P62 was related to autophagy level negatively[37]. The results of Western Blot showed that after adding to isatin like before, the protein relative expression of P62 of SH-SY5Y cell was decreased. The antitumor effect of autophagy on tumor was induced by certain ATG protein by report, such as Beclin1 [38]. The results of Western Blot showed that SH-SY5Y cells treatment with isatin like above, the protein relative expression of P62 was increased. The results of this study revealed that autophagy was related with isatin, which provided a novel mechanism for isatin to act on NB. 


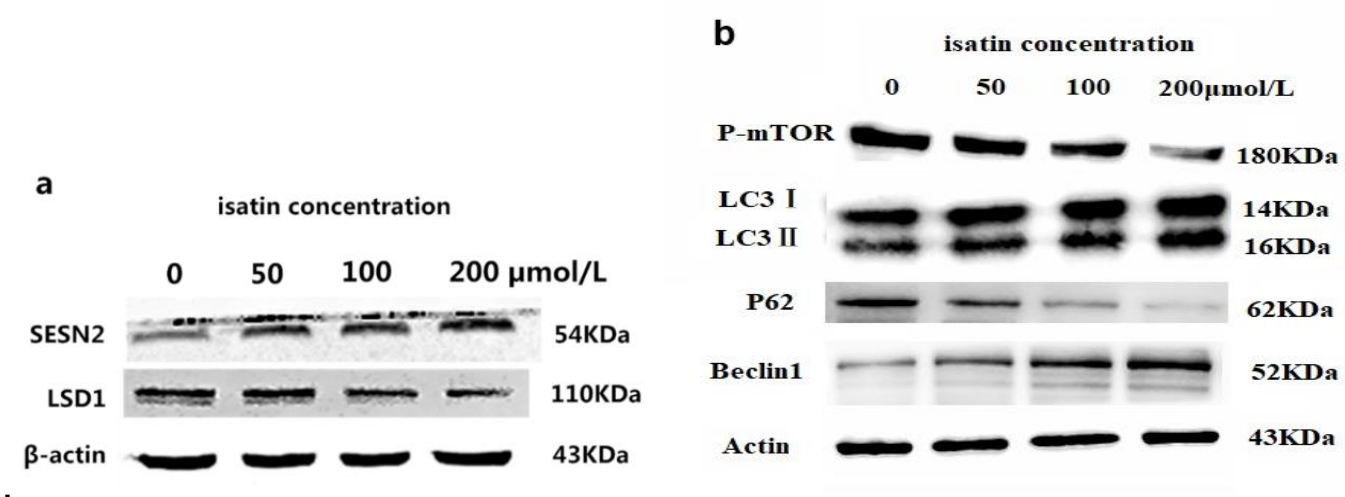

C
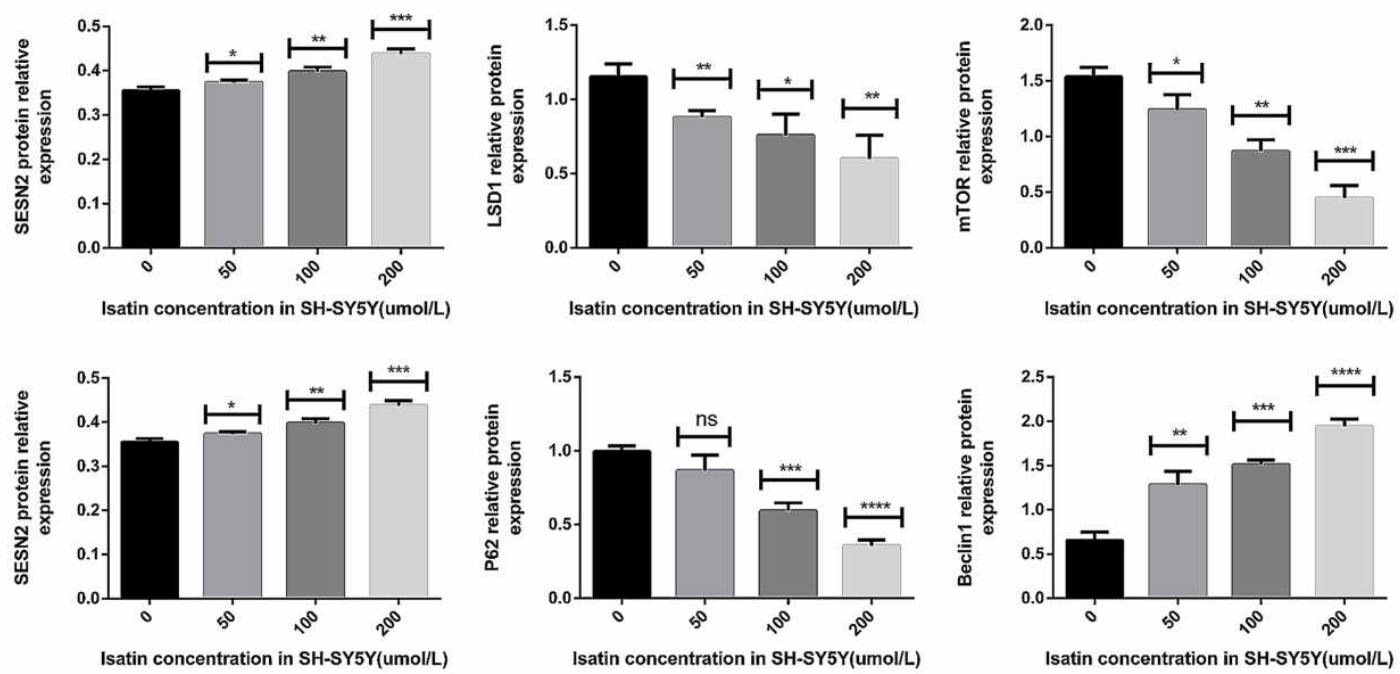

Fig. 7 Western Blot detect protein relative expression. In SH-SY5Y cells LSD1, SESN2, Beclin1, P62 and LC3 relative protein expression changed $(P<0.01)$ after adding to different concentrations isatin for $48 \mathrm{~h}$.

\section{Discussion}

Isatin is a derivative of anticarcinogen indirubin, it exhibited many beneficial biological activities, including antifungal, antibacterial anticancer capabilities. The CCK8 results had revealed that the SH-SY5Y cells were deal with isatin at doses ranging from 50 to $200 \mu \mathrm{mol} / \mathrm{L}$ could be able to inhibit tumor cell growth effectively. The flow cytometry and the DAPI staining results indicated that isatin could trigger SH-SY5Y cells apoptosis, and the tablet cloning results declared isatin suppressed the cells proliferation, and the scratch 
experiment and the Transwell results further illustrated that isatin could restrain invasion and metastasis of NB cells SH-SY5Y. All of the above cell function experiments explained that isatin had inhibitory effect on NB SHSY5Y cells, and provided a basis for further animal and human experiments. Moreover, the results from qPCR and Western Blot also evaluated that the potential fuction of isatin on induction of autophagy effectively in human NB cell SH-SY5Y. Collectively, the results not only identified the attended of autophagy in the antitumor performance of isatin, but also further provided a new molecular mechanism to understan isatin inhibited NB by inducing autophagy, as well as the theoretical basis for the development of chemotherapy medicine for neuroblastoma.

Autophagy is an important process that senses the changes of intracellular environment, and it make cell contribution to acclimatize oneself to adverse environments, such as energy insufficiency, nutrient depletion, and other cellular stress environments [39]. Autophagy play dual roles in tumor and defective autophagy is associated with cancer[40, 41]. Autophagy can be used as a neoplam inhibitor by preventing the accumulation of damaged proteins and organelles, or by inhibiting apoptosis and accelerating the survival pathway of cancer growth[35, 42, 43]. The results from qPCR and Western Blot from our present study showed that treatment with relatively doses of isatin could regulate the expression of autophagy-related proteins, this suggested that isatin was likely to activate autophagy in NB cells SH- 
SY5Y, other experiments still proved that the apoptosis of NB cells SH-SY5Y increased after dealing with isatin, thus, the SH-SY5Y cells underwent apoptosis and autophagy after the addition of isatin, and apoptosis and autophagy promoted each other and jointly restrained the growth of NB cells. However, how isatin actived autophagy in NB SH-SY5Y cells and the mechanisms involved are unclear, so the molecular mechanism underlying relationship between autophagy and tumor still need further investigated. Lately, some reports display that epigenetic alterations were related to autophagy, such as the methylation and acetylation of histone[14, 38]. There has been no assessment for the mechanism that regulation of autophagy by tumor associated epigenetic alterations. LSD1 as an epigenetic enzyme had been a target of isatin. Overexpression of LSD1 was closely related to tumor development. Inhibition LSD1 of triggered autophagy, as well as could reduce the expression of mTORC1, led to TFEB nuclear translocation, cause LC3-II accumulated and autophagosomes are formed in the end, This showed that a LSD1-specific transcriptional regulation is directly related to mTORC1 cascade and autophagy[32]. Isatin acts as an inhibitor of LSD1, we found the expression level of LSD1 decreased after the addition of isatin to SH-SY5Y cells, and the results from qPCR and Western Blot show that the relative expression level of mRNA and protein of mTOR decreased significantly. Therefore, isatin was likely to control autophagy by depressing the relative expression of LSD1 and then cause a change in mTOR signaling pathway. In 
order to prove that autophagy occurred in cells, we further detected the expression of autophagy related-proteins by QPCR and Western Blot experiments, such as LC3, P62, Beclin1, and qPCR and Western Blot results found that there were both statistically significant changes in these genes, the relative expression levels of mRNA and protein of LC3 and Beclin1 increased significantly, while P62 decreased significantly. Lately research indicated that the mTOR pathway may be associated with cancer-related epigenetic alterations[44-46]. All above results showed that isatin-exposed in SH-SY5Y cells inhibit LSD1 regulated autophagy through the mTOR pathway. But what interested us was that after isatin inhibiting LSD1, how did it induce autophagy in the mTOR signaling pathway. Therefore, we searched a large number of literatures and filtered the results through KEGG database, finally it found that SESN2 was probably involved in mTOR pathway regulated autophagy induced by LSD1. SESN2 was reported to be related to oxidative stressinduced autophagy[47]. According to report, it found that SESN2 promoter was directly bound and repressed by LSD1; pharmacological inhibition of LSD1 triggered a structural modeling in the chromatin surrounding the TSS of the SESN2 gene, leading to transcriptional activation of SESN2 [32]. Moreover, from the experimental results, the expression of mRNA and protein of SESN2 were increased significantly after isatin was added to SH-SY5Y cells. From this data, it identified that SESN2 involved in autophagy as an LSD1-repressed target gene. This article provided firstly evidence to support 
the role of LSD1 as an epigenetic regulator of the autophagic pathway through the modulation of SESN2 expression. However, the above analysis explained that isatin can inhibit neuroblastoma by inhibiting the activity of LSD1 enzyme and change SESN2 expression at the epigenetic level, then affect autophagy. The discovery here indicated that the mTOR pathway involve in autophagy induction by isatin addition in SH-SY5Y cells, it suggested that the mTOR pathway is a new key pathway for SESN2 induction that can cause activity of autophagy and repress the growth of tumor cells. In summary, this study provides a new mechanism for how isatin inhibits neuroblastoma. First isatin as LSD1 inhibitors can directly inhibit the expression of LSD1, and at transcription level through causeing the changes of downstream genes expression of LSD1target genes SESN2's quantity change, again through the mTOR signaling pathways leading to the change of autophagy-related proteins, ultimately activate autophagy, at the same time, there have also occur in apoptosis, so as to under the action of autophagy and apoptosis, inhibiting tumor cell growth. But the mechanism of isatin inducing autophagy and apoptosis remains to be further investigated, and further animal and clinical trials are needed to develop isatin into a clinical cancer drug, So there's a lot of research and work that needs to be done. Nevertheless, this paper provides a new approach to the mechanism of isatin inhibits neuroblastoma, and a theoretical basis for the anti-tumor effect of isatin on NB, finally demonstrating the potential of isatin to develop anticancer 
drugs for neuroblastoma and other tumors.

\section{Conclusions}

Isatin inhibits the growth of neuroblastoma, possibly by activating autophagy and by acting in conjunction with apoptosis, demonstrating the potential of isatin to be a chemotherapy agent for neuroblastoma.

\section{Availability of data and materials}

All data generated or analyzed during this study are included in this published article and its supplementary information files.

\section{Abbreviations}

\section{NB: Neuroblastoma}

LSD1: Lysine-specific demethylase 1

SESN2: Sestrin2

LC3: Autophagy microtubule-associated protein light chain 3:

P62: Nucleopore glycoproteinP62

mTOR: Mammalian target of rapamycin

MAOB : Monoamine oxidase B

MAO : Monoamine oxidase

DAPI: Diaminophenylindoles

PBS: Phosphate buffer solution

q-PCR: Real-time quantitativePCR

\section{References}

1. Costa RA, Seuanez HN: Investigation of major genetic alterations in neuroblastoma. 2018, 45(3):287-295.

2. Braekeveldt N, Bexell D: Patient-derived xenografts as preclinical neuroblastoma models. Cell Tissue Res 2018, 372(2):233-243.

3. Kholodenko IV, Kalinovsky DV, Doronin II, Deyev SM, Kholodenko RV: Neuroblastoma Origin and Therapeutic Targets for Immunotherapy. $J$ Immunol Res 2018, 2018:7394268-7394268.

4. Cohn SL, Pearson ADJ, London WB, Monclair T, Ambros PF, Brodeur GM, Faldum A, Hero B, Iehara T, Machin D et al: The International Neuroblastoma Risk Group (INRG) classification system: an INRG Task Force report. Journal of clinical oncology : official journal of the American 
Society of Clinical Oncology 2009, 27(2):289-297.

5. Singh GS, Desta ZY: Isatins as privileged molecules in design and synthesis of spiro-fused cyclic frameworks. Chemical reviews 2012, 112(11):61046155.

6. Chiyanzu I, Hansell E, Gut J, Rosenthal PJ, McKerrow JH, Chibale K: Synthesis and evaluation of isatins and thiosemicarbazone derivatives against cruzain, falcipain-2 and rhodesain. Bioorganic \& medicinal chemistry letters 2003, 13(20):3527-3530.

7. Verma M, Pandeya SN, Singh KN, Stables JP: Anticonvulsant activity of Schiff bases of isatin derivatives. Acta pharmaceutica (Zagreb, Croatia) 2004, 54(1):49-56.

8. Gencer N, Sonmez F, Demir D, Arslan O, Kucukislamoglu M: Synthesis, structure-activity relationships and biological activity of new isatin derivatives as tyrosinase inhibitors. Current topics in medicinal chemistry 2014, 14(12):1450-1462.

9. Igosheva N, Lorz C, O'Conner E, Glover V, Mehmet H: Isatin, an endogenous monoamine oxidase inhibitor, triggers a dose- and timedependent switch from apoptosis to necrosis in human neuroblastoma cells. Neurochemistry international 2005, 47(3):216-224.

10. Zhong H, Chiles K, Feldser D, Laughner E, Hanrahan C, Georgescu MM, Simons JW, Semenza GL: Modulation of hypoxia-inducible factor 1alpha expression by the epidermal growth factor/phosphatidylinositol 3kinase/PTEN/AKT/FRAP pathway in human prostate cancer cells: implications for tumor angiogenesis and therapeutics. Cancer Res 2000, 60(6):1541-1545.

11. Fitzgerald JC, Ufer C, Billett EE: A link between monoamine oxidase-A and apoptosis in serum deprived human SH-SY5Y neuroblastoma cells. $J$ Neural Transm (Vienna) 2007, 114(6):807-810.

12. Lin Y, Wu Y, Li J, Dong C, Ye X, Chi Y-I, Evers BM, Zhou BP: The SNAG domain of Snail1 functions as a molecular hook for recruiting lysinespecific demethylase 1. The EMBO journal 2010, 29(11):1803-1816.

13. Artal-Martinez de Narvajas A, Gomez TS, Zhang JS, Mann AO, Taoda Y, Gorman JA, Herreros-Villanueva M, Gress TM, Ellenrieder V, Bujanda L et al: Epigenetic regulation of autophagy by the methyltransferase G9a. Molecular and cellular biology 2013, 33(20):3983-3993.

14. Eisenberg T, Schroeder S, Andryushkova A, Pendl T, Kuttner V, Bhukel A, Marino G, Pietrocola F, Harger A, Zimmermann A et al: Nucleocytosolic depletion of the energy metabolite acetyl-coenzyme a stimulates autophagy and prolongs lifespan. Cell metabolism 2014, 19(3):431-444.

15. Lapierre LR, Kumsta C, Sandri M, Ballabio A, Hansen M: Transcriptional and epigenetic regulation of autophagy in aging. Autophagy 2015, 11(6):867-880.

16. Shi Y, Lan F, Matson C, Mulligan P, Whetstine JR, Cole PA, Casero RA, Shi $Y$ : Histone demethylation mediated by the nuclear amine oxidase homolog 
LSD1. Cell 2004, 119(7):941-953.

17. Lan F, Nottke AC, Shi Y: Mechanisms involved in the regulation of histone lysine demethylases. Current opinion in cell biology 2008, 20(3):316-325.

18. Metzger E, Wissmann M, Yin N, Muller JM, Schneider R, Peters AH, Gunther T, Buettner R, Schule R: LSD1 demethylates repressive histone marks to promote androgen-receptor-dependent transcription. Nature 2005, 437(7057):436-439.

19. Wang $\mathrm{J}$, Telese $\mathrm{F}$, Tan Y: LSD1n is an H4K20 demethylase regulating memory formation via transcriptional elongation control. 2015, 18(9): 1256-1264.

20. Huang J, Sengupta R, Espejo AB, Lee MG, Dorsey JA, Richter M, Opravil S, Shiekhattar R, Bedford MT, Jenuwein T et al: p53 is regulated by the lysine demethylase LSD1. Nature 2007, 449(7158):105-108.

21. Kontaki H, Talianidis I: Lysine methylation regulates E2F1-induced cell death. Molecular cell 2010, 39(1):152-160.

22. Wang J, Hevi S, Kurash JK, Lei H, Gay F, Bajko J, Su H, Sun W, Chang H, $\mathrm{Xu} \mathrm{G}$ et al: The lysine demethylase LSD1 (KDM1) is required for maintenance of global DNA methylation. Nature genetics 2009, 41(1):125129.

23. Amente S, Lania L, Majello B: The histone LSD1 demethylase in stemness and cancer transcription programs. Biochimica et biophysica acta 2013, 1829(10):981-986.

24. Ambrosio S, Amente S, Sacca CD, Capasso M, Calogero RA, Lania L, Majello B: LSD1 mediates MYCN control of epithelial-mesenchymal transition through silencing of metastatic suppressor NDRG1 gene. Oncotarget 2017, 8(3):3854-3869.

25. Han X, Gui B, Xiong C, Zhao L, Liang J, Sun L, Yang X, Yu W, Si W, Yan R et al: Destabilizing LSD1 by Jade-2 promotes neurogenesis: an antibraking system in neural development. Molecular cell 2014, 55(3):482494.

26. Lim S, Janzer A, Becker A, Zimmer A, Schule R, Buettner R, Kirfel J: Lysinespecific demethylase 1 (LSD1) is highly expressed in ER-negative breast cancers and a biomarker predicting aggressive biology. Carcinogenesis 2010, 31(3):512-520.

27. Yokoyama A, Igarashi K, Sato T, Takagi K, Otsuka IM, Shishido Y, Baba T, Ito R, Kanno J, Ohkawa $\mathrm{Y}$ et al: Identification of myelin transcription factor 1 (MyT1) as a subunit of the neural cell type-specific lysine-specific demethylase 1 (LSD1) complex. The Journal of biological chemistry 2014, 289(26):18152-18162.

28. Stambolic V, Suzuki A, de la Pompa JL, Brothers GM, Mirtsos C, Sasaki T, Ruland J, Penninger JM, Siderovski DP, Mak TW: Negative regulation of PKB/Akt-dependent cell survival by the tumor suppressor PTEN. Cell 1998, 95(1):29-39.

29. Shao GB, Huang XJ, Gong AH, Zhang ZJ, Lu RZ, Sang JR: [Histone 
demethylase LSD1 and its biological functions]. Yi chuan = Hereditas 2010, 32(4):331-338.

30. Sun G, Alzayady K, Stewart R, Ye P, Yang S, Li W, Shi Y: Histone demethylase LSD1 regulates neural stem cell proliferation. Molecular and cellular biology 2010, 30(8):1997-2005.

31. Wang LX, Zhu XM, Yao YM: Sestrin2: Its Potential Role and Regulatory Mechanism in Host Immune Response in Diseases. Front Immunol 2019, 10:2797.

32. Ambrosio S, Sacca CD, Amente S, Paladino S, Lania L, Majello B: Lysinespecific demethylase LSD1 regulates autophagy in neuroblastoma through SESN2-dependent pathway. Oncogene 2017, 36(48):6701-6711.

33. Zhang L, Sun W, Cao Y, Hou L, Ju C, Wang X: Isatin inhibits the invasion of human neuroblastoma SHSY5Y cells, based on microarray analysis. Mol Med Rep 2019, 20(2):1700-1706.

34. Zhang L, Sun W, Cao Y, Hou L, Ju C, Wang X: Isatin inhibits the invasion of human neuroblastoma SH-SY5Y cells, based on microarray analysis.

Molecular medicine reports 2019, 20(2):1700-1706.

35. White E: The role for autophagy in cancer. The Journal of clinical investigation 2015, 125(1):42-46.

36. Yang ZJ, Chee CE, Huang S, Sinicrope FA: The role of autophagy in cancer: therapeutic implications. Molecular cancer therapeutics 2011, 10(9):15331541.

37. Santoni M, Amantini C, Morelli MB, Liberati S, Farfariello V, Nabissi M, Bonfili L, Eleuteri AM, Mozzicafreddo M, Burattini L et al: Pazopanib and sunitinib trigger autophagic and non-autophagic death of bladder tumour cells. Br J Cancer 2013, 109(4):1040-1050.

38. Sehgal AR, Konig H, Johnson DE, Tang D, Amaravadi RK, Boyiadzis M, Lotze MT: You eat what you are: autophagy inhibition as a therapeutic strategy in leukemia. Leukemia 2015, 29(3):517-525.

39. Altman BJ, Rathmell JC: Metabolic stress in autophagy and cell death pathways. Cold Spring Harbor perspectives in biology 2012, 4(9):a008763.

40. Levine B, Mizushima N, Virgin HW: Autophagy in immunity and inflammation. Nature 2011, 469(7330):323-335.

41. Maiese K: Targeting molecules to medicine with mTOR, autophagy and neurodegenerative disorders. British journal of clinical pharmacology 2016, 82(5): 1245-1266.

42. Jiang P, Mizushima N: Autophagy and human diseases. Cell research 2014, 24(1):69-79.

43. Maiuri MC, Zalckvar E, Kimchi A, Kroemer G: Self-eating and self-killing: crosstalk between autophagy and apoptosis. Nature reviews Molecular cell biology 2007, 8(9):741-752.

44. Fullgrabe J, Klionsky DJ, Joseph B: The return of the nucleus: transcriptional and epigenetic control of autophagy. Nature reviews Molecular cell biology 2014, 15(1):65-74. 
45. Maiuri MC, Tasdemir E, Criollo A, Morselli E, Vicencio JM, Carnuccio R, Kroemer G: Control of autophagy by oncogenes and tumor suppressor genes. Cell death and differentiation 2009, 16(1):87-93.

46. Galluzzi L, Pietrocola F, Bravo-San Pedro JM, Amaravadi RK, Baehrecke EH, Cecconi F, Codogno P, Debnath J, Gewirtz DA, Karantza V et al: Autophagy in malignant transformation and cancer progression. The EMBO journal 2015, 34(7):856-880.

47. Liang Y, Zhu J, Huang H, Xiang D, Li Y, Zhang D, Li J, Wang Y, Jin H, Jiang $\mathrm{G}$ et al: SESN2/sestrin $\mathbf{2}$ induction-mediated autophagy and inhibitory effect of isorhapontigenin (ISO) on human bladder cancers. Autophagy 2016, 12(8):1229-1239.

\section{Acknowledgements}

I would like to thank my mentor Lin Hou, my seniors and classmates for their help.

\section{Funding}

This study was supported by the National Natural Science Foundation of

China (grant no. 81472542), the Focus on Research and Development Plan in Shandong Province (grant no. 2019GSF107025), the Clinical Medicine $+X$

Project of the Medical Department of Qingdao University and Innovation Team of Qingdao University Medical School Youth Teacher Training Project (grant no. 600201304), Qingdao Startup and Innovation Leader Talent Plan(13-CX-3,201409-201709).

\section{Affiliations}

Department of Biochemistry and Molecular Biology, School of Basic Medicine, Qingdao University, Qingdao, China.

Experimental Center for Undergraduates of Pharmacy, School of Pharmacy; Qingdao University, Qingdao, Shandong, China. 


\section{Corresponding author}

Correspondence to Lin Hou.

\section{Ethics declarations}

\section{Ethics approval and consent to participate}

The study was approved by the Institutional Qingdao University. Waivers of informed consent was approved by the Institutional Review board.

\section{Consent for publication}

For this type of study, formal consent is not required. Informed consent was obtained from all individual participants included in the study.

\section{Competing interests}

The authors declare that they have no competing interests.

Author Xue Li declares that he has no conflict of interest. Author Li Zhang declares that he has no conflict of interest. Author Yiming Nai declares that he has no conflict of interest. Author Fangling Wang declares that he has no conflict of interest. Author Yanan Hua declares that he has no conflict of interest. Author Na Zhou declares that he has no conflict of interest. Author Jun Wang declares that he has no conflict of interest. Author Wenxiang Zheng declares that he has no conflict of interest. 


\section{Figures}

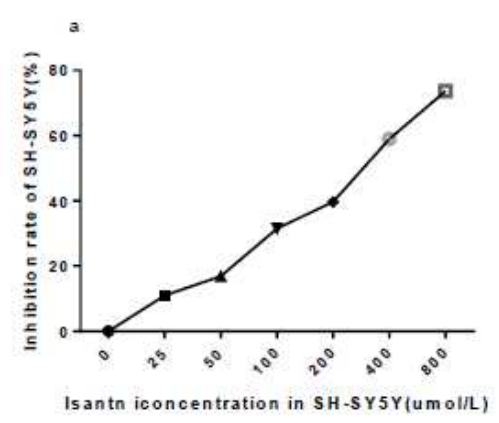

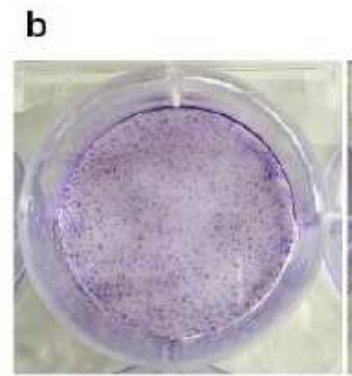

$0 \mu \mathrm{mol} / \mathrm{L}$

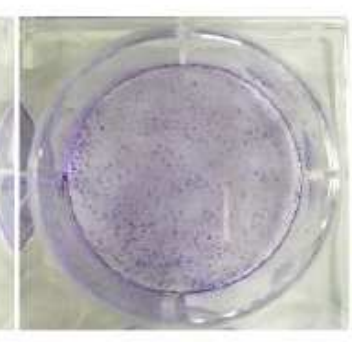

$50 \mu \mathrm{mol} / \mathrm{L}$

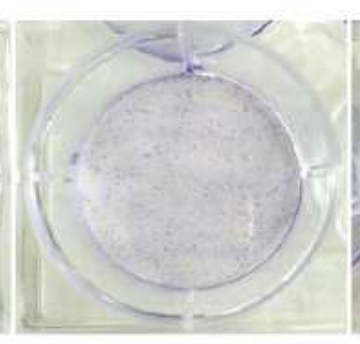

$100 \mu \mathrm{mol} / \mathrm{L}$

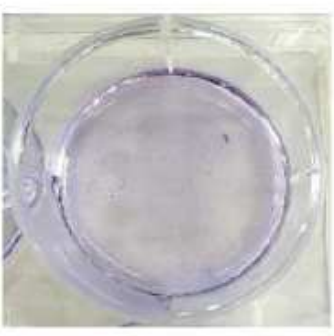

$200 \mu \mathrm{mol} / \mathrm{L}$

\section{Figure 1}

Isatin inhibited SH-SY5Y cells proliferation. a CCK-8 assay showed that isatin inhibited the proliferation of SH-SY5Y cells. b Tablet cloning showed SH-SY5Y cells were treatment with $0 \mu \mathrm{mol} / \mathrm{L}, 50 \mu \mathrm{mol} / \mathrm{L}, 100$ $\mu \mathrm{mol} / \mathrm{L}, 200 \mu \mathrm{mol} / \mathrm{L}$ isatin for $48 \mathrm{~h}$, cell cloning was significantly inhibited.

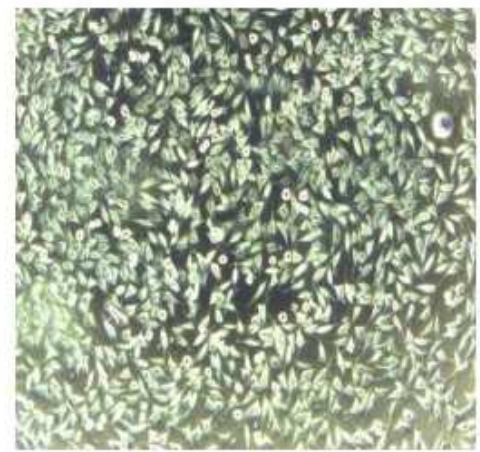

$0 \mu \mathrm{mol} / \mathrm{L}$

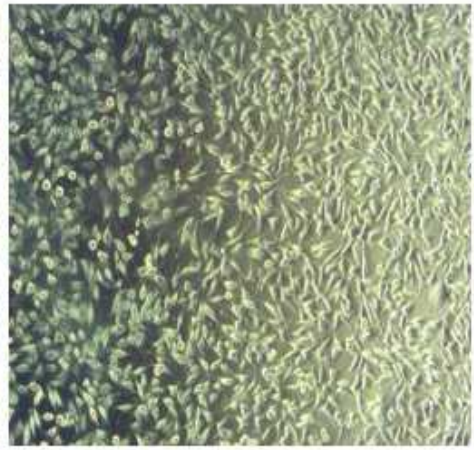

$50 \mu \mathrm{mol} / \mathrm{L}$

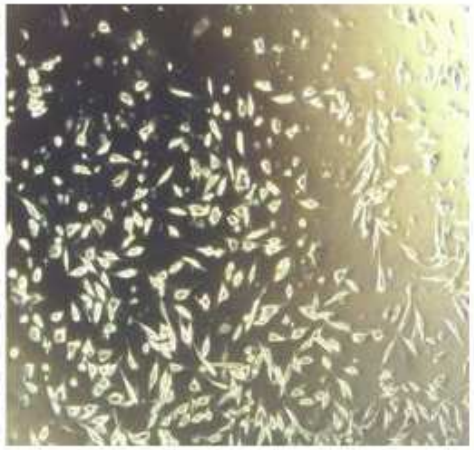

$100 \mu \mathrm{mol} / \mathrm{L}$

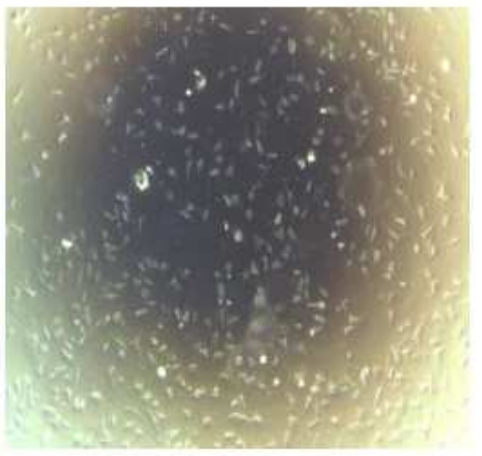

$200 \mu \mathrm{mol} / \mathrm{L}$

Figure 2

SH-SY5Y cells were treatment with isatin for $48 \mathrm{~h}$, Cell morphology changed. 
a

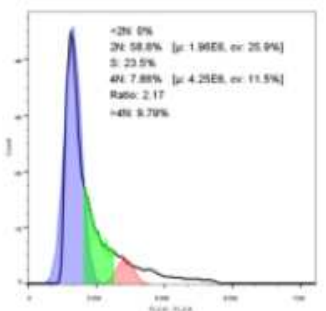

$0 \mu \mathrm{mol} / \mathrm{L}$

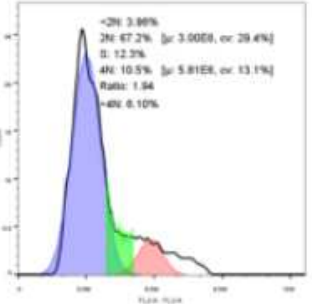

$50 \mu \mathrm{mol} / \mathrm{L}$

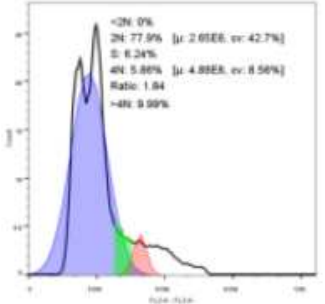

$100 \mu \mathrm{mol} / \mathrm{L}$

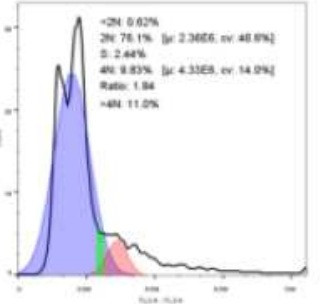

$200 \mu \mathrm{mol} / \mathrm{L}$

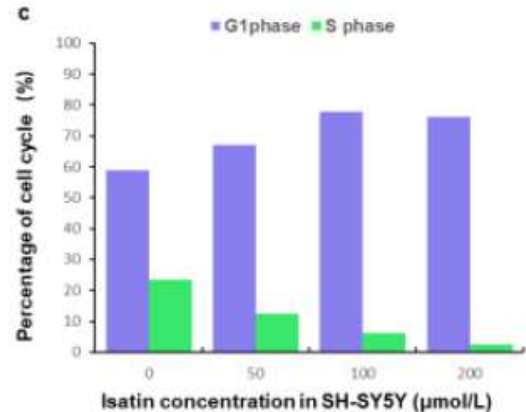

b

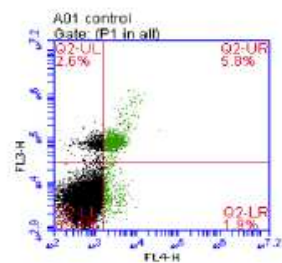

$0 \mu \mathrm{mol} / \mathrm{L}$

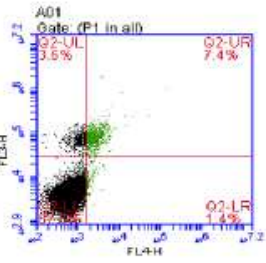

$50 \mu \mathrm{mol} / \mathrm{L}$

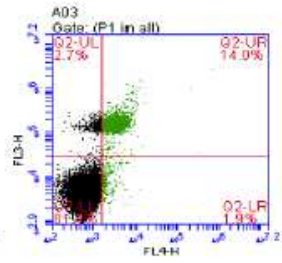

$100 \mu \mathrm{mol} / \mathrm{L}$

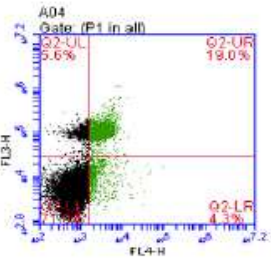

$200 \mu \mathrm{mol} / \mathrm{L}$

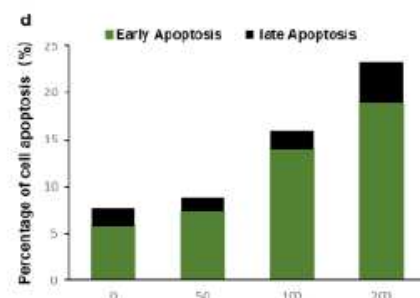

Isatin concontration in SH-SYSY ( $\mu$ mollL)

Figure 3

Flow cytometry to detect cell cycle and apoptosis. A SH-SY5Y cells were treatment with different isatin, flow cytometry to detect the change of cell cycle. B SH- SY5Y cells were treatment with different concentrations isatin, flow cytometry to detect the change of cell apoptosis. c was percentage of cell cycle after adding to different concentrations isatin in SH-SY5Y cells from a. $d$ was percentage of cell apoptosis after adding to different concentrations isatin in SH-SY5Y cells from b.

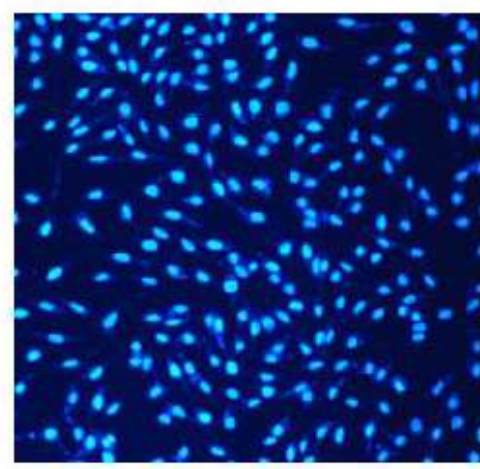

$0 \mu \mathrm{mol} / \mathrm{L}$

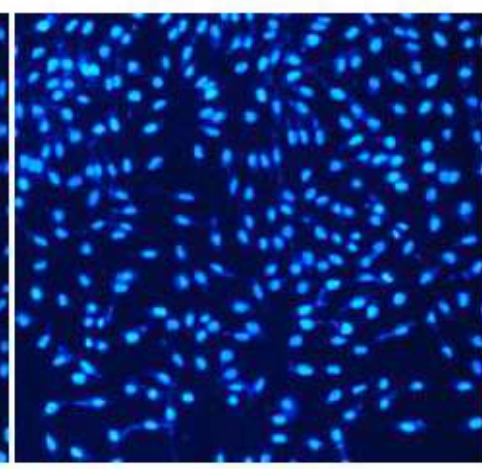

$50 \mu \mathrm{mol} / \mathrm{L}$

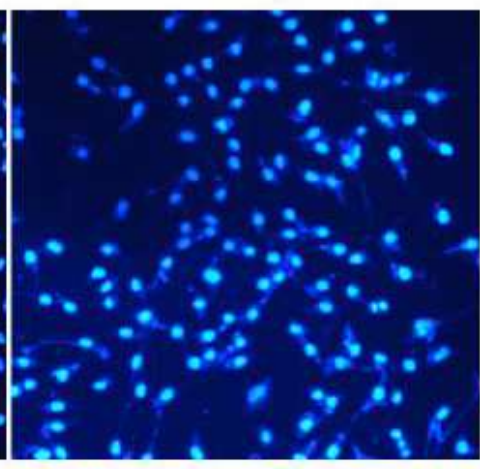

$100 \mu \mathrm{mol} / \mathrm{L}$

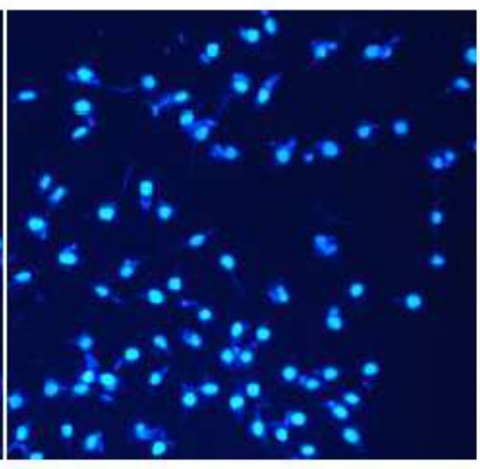

$200 \mu \mathrm{mol} / \mathrm{L}$

\section{Figure 4}

DAPI staining to detect apoptosis. SH-SY5Y cells were treatment with $0 \mu \mathrm{mol} / \mathrm{L}, 50 \mu \mathrm{mol} / \mathrm{L}, 100 \mu \mathrm{mol} / \mathrm{L}$, $200 \mu \mathrm{mol} / \mathrm{L}$ isatin, the morphology of the nucleus changed. 
a

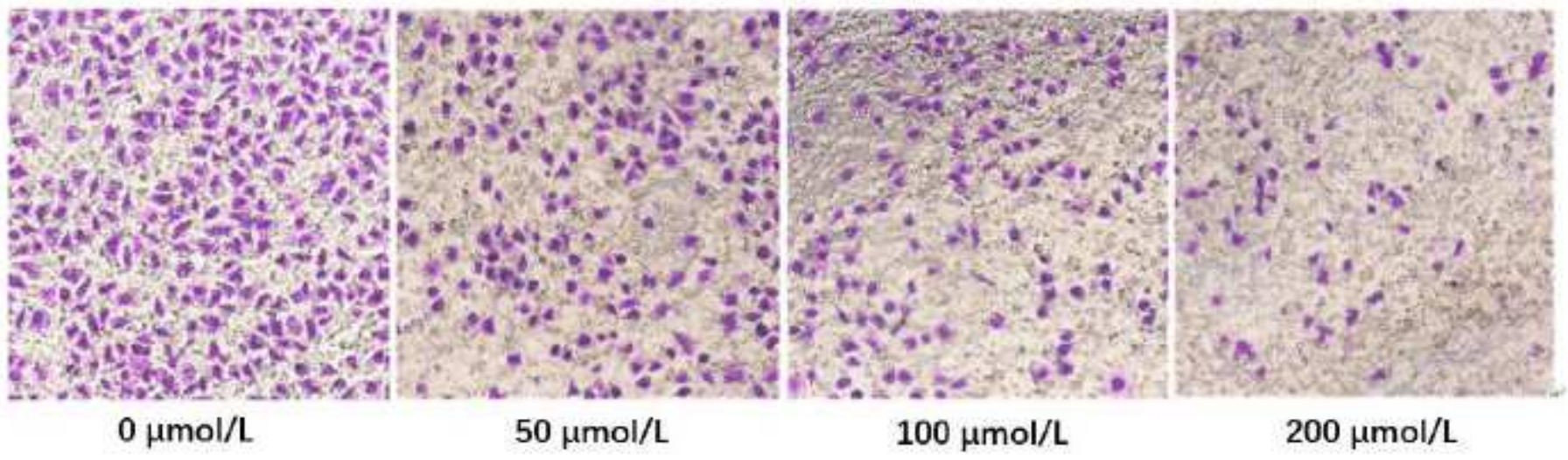

b
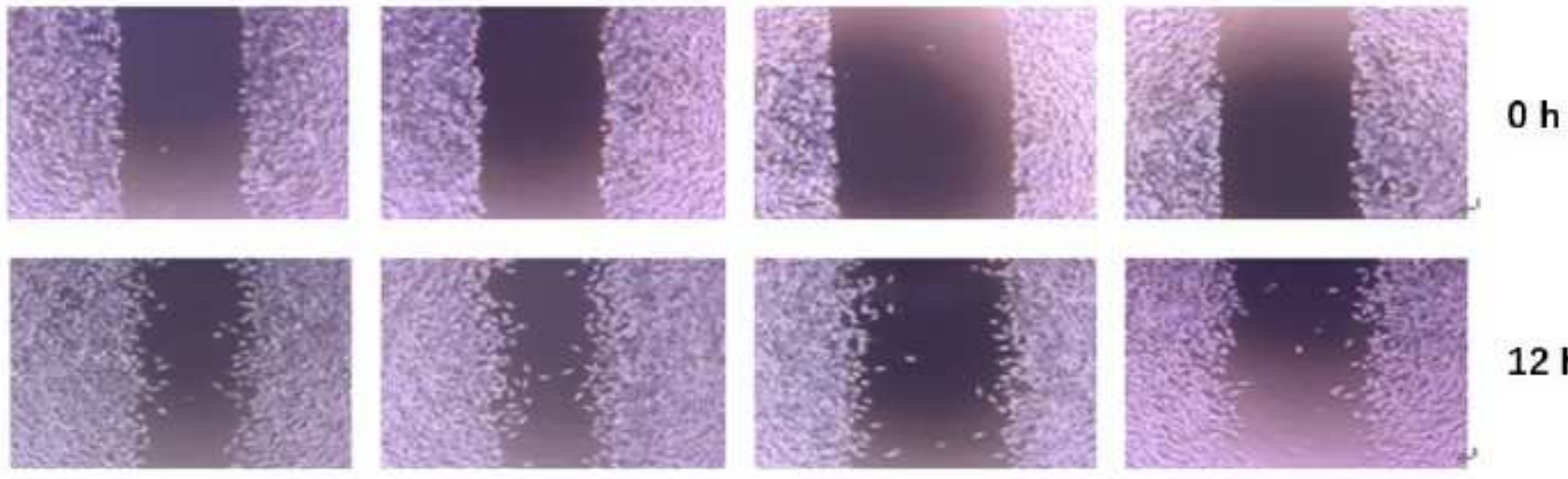

$12 \mathrm{~h}$
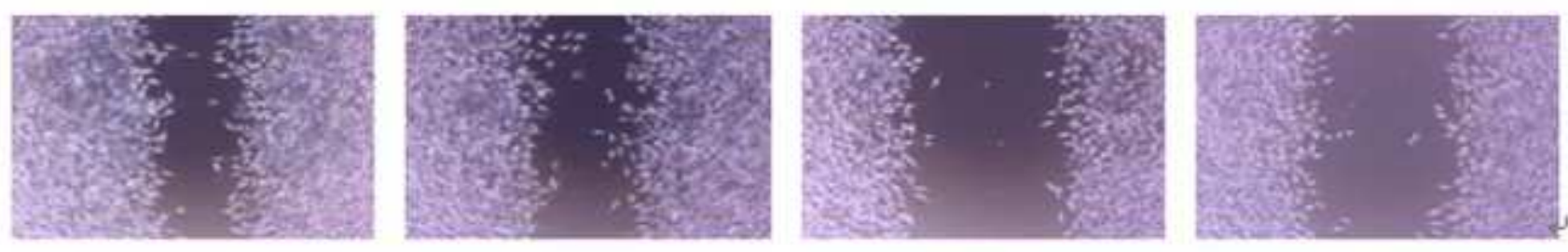

$24 \mathrm{~h}$

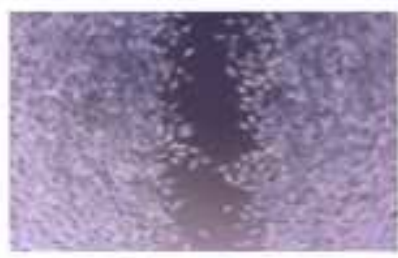

$0 \mu \mathrm{mol} / \mathrm{L}$

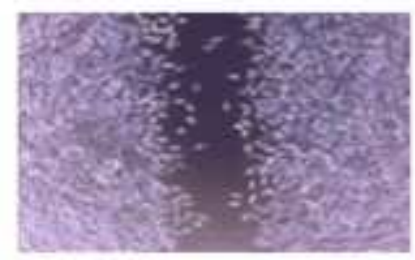

$50 \mu \mathrm{mol} / \mathrm{L}$

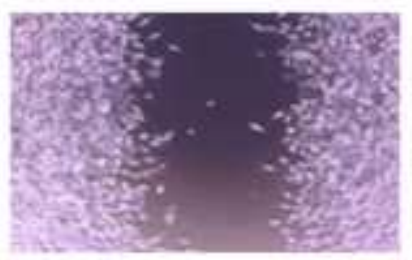

$100 \mu \mathrm{mol} / \mathrm{L}$

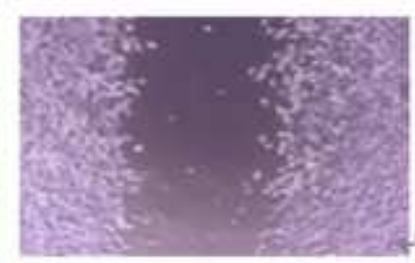

$200 \mu \mathrm{mol} / \mathrm{L}$

\section{$36 \mathrm{~h}$}

\section{Figure 5}

Isatin suppressed SH-SY5Y cells invasion and migration. a SH-SY5Y cells were treatment with $0 \mu \mathrm{mol} / \mathrm{L}$, $50 \mu \mathrm{mol} / \mathrm{L}, 100 \mu \mathrm{mol} / \mathrm{L}, 200 \mu \mathrm{mol} / \mathrm{L}$ isatin, the invasion of cells were obviously inhibited. b SH-SY5Y cells were treatment with $0 \mu \mathrm{mol} / \mathrm{L}, 50 \mu \mathrm{mol} / \mathrm{L}, 100 \mu \mathrm{mol} / \mathrm{L}, 200 \mu \mathrm{mol} / \mathrm{L}$ isatin, the migration of cells was obviously inhibited. 


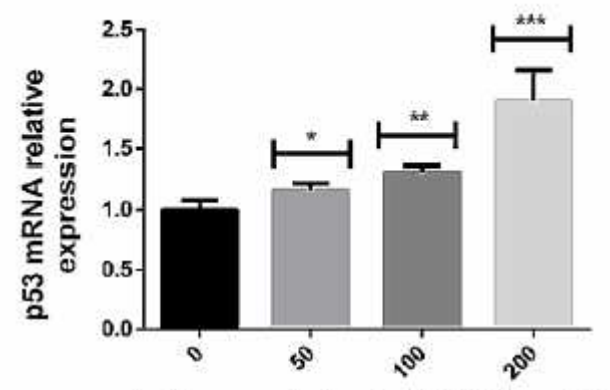

Isatin concentration in SH-SY5Y(umol/L)

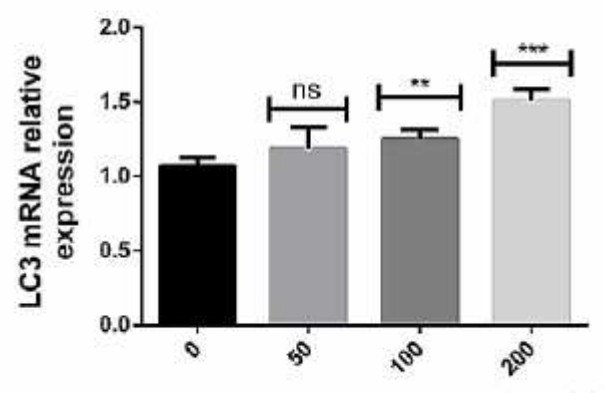

Isatin concentration in SH-SY5Y(umol/L)

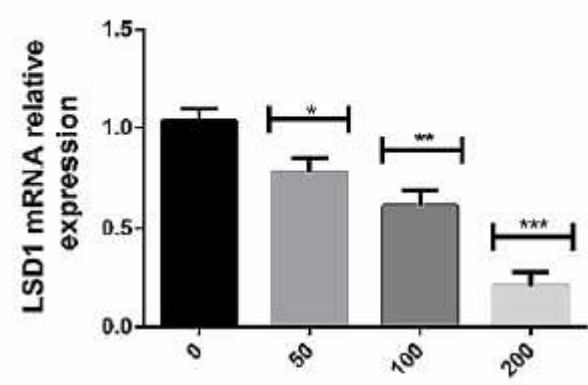

Isatin concentration in SH-SY5Y(umol/L)

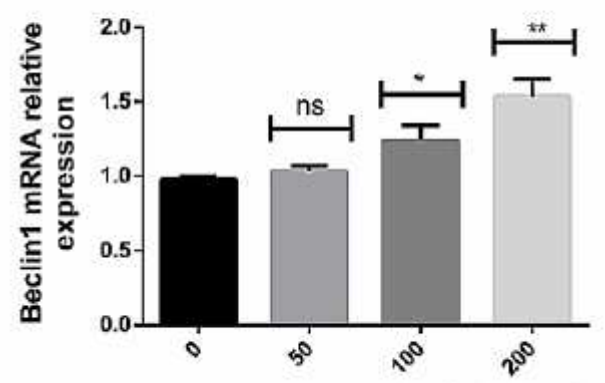

Isatin concentration in SH-SY5Y(umol/L)

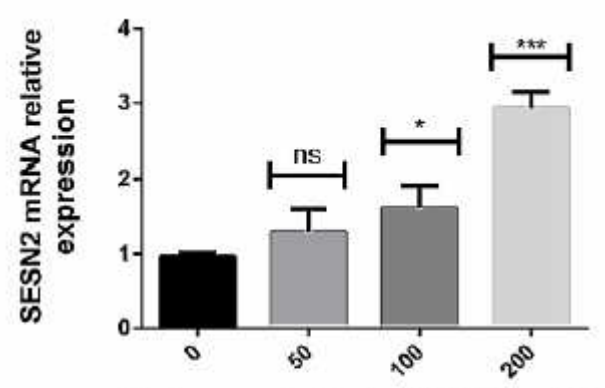

Isatin concentration in SH-SY5Y(umol/L)

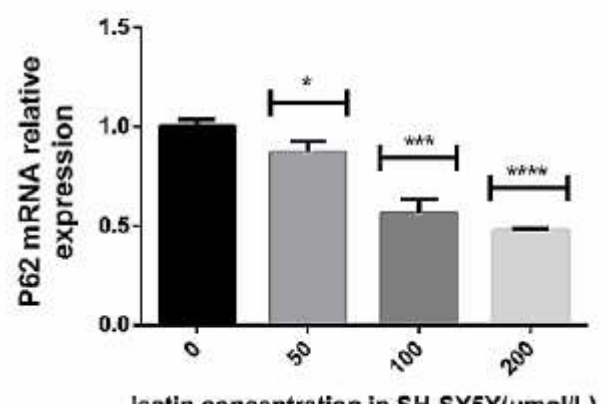

Isatin concentration in SH-SY5Y(umol/L)

Figure 6

q-PCR assay detect mRNA relative expression. In SH-SY5Y cells p53, LSD1, SESN2, Beclin1, P62 and LC3 changed $(P<0.01)$ after adding to different concentrations isatin for $48 \mathrm{~h}$. 


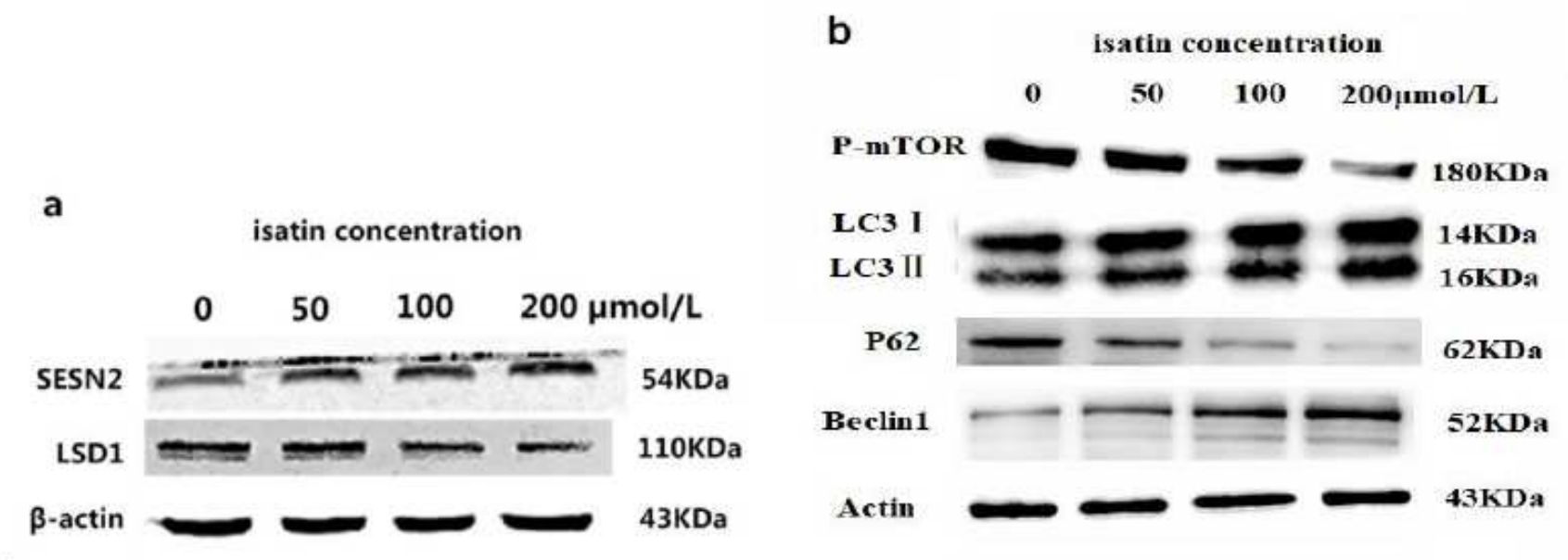

C

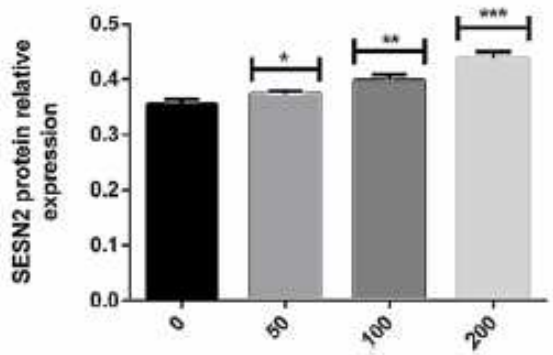

Isatin concentration in SH-SY5Y(umol/L)

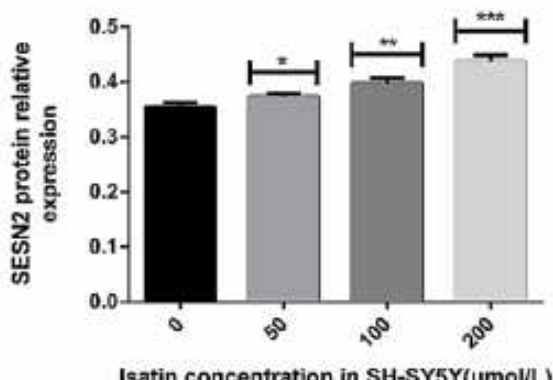

Isatin concentration in SH-SY5Y(umol/L)

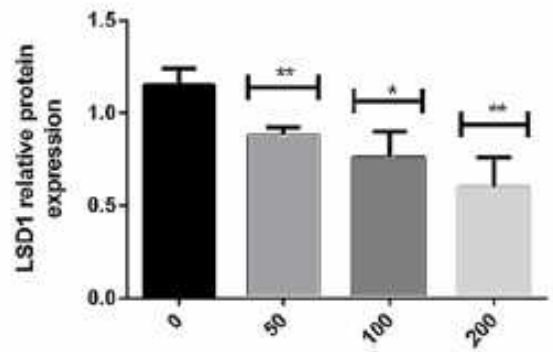

Isatin concentration in SH-SY5Y(umol/L)

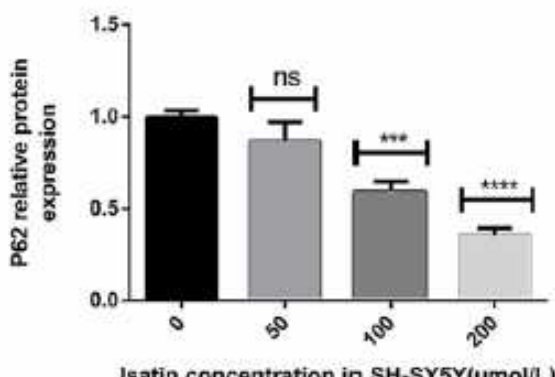

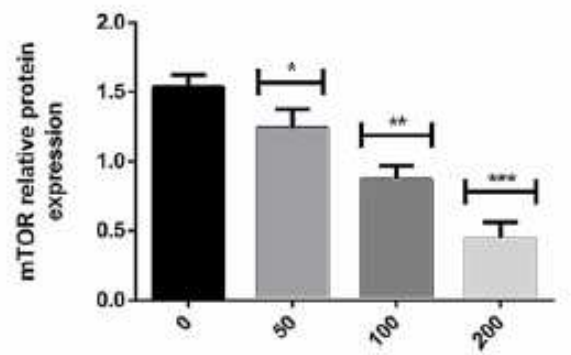

Isatin concentration in SH-SY5Y(umol/L)

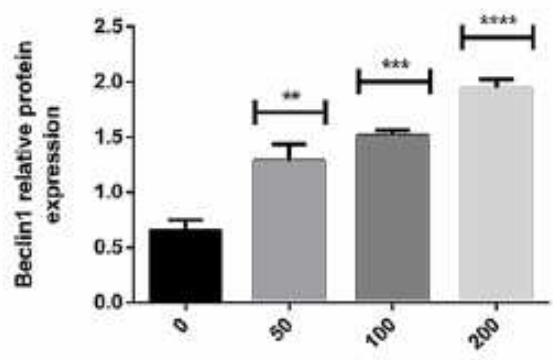

Isatin concentration in SH-SY5Y(umol/L)

Figure 7

Western Blot detect protein relative expression. In SH-SY5Y cells LSD1, SESN2, Beclin1, P62 and LC3 relative protein expression changed $(P<0.01)$ after adding to different concentrations isatin for $48 \mathrm{~h}$. 